\title{
Electrospun Composite of $\mathrm{Fe}_{3} \mathrm{O}_{4} / \mathrm{Cu}$ Nanocrystals Encapsulated in Carbon Fibers as an Anode Material with High Rate Capability for Lithium Ion Batteries
}

\author{
Meng ZHANG ${ }^{1, a}$, Jing WANG ${ }^{1,2, b^{*}}$, Shi CHEN $^{1,2, c}$ and Feng WU ${ }^{1,2, d}$ \\ ${ }^{1}$ School of Materials Science and Engineering, Beijing Key Laboratory of Environmental Science \\ and Engineering, Beijing Institute of Technology, Beijing, 100081, China \\ ${ }^{2}$ Collaborative Innovation Center of Electric Vehicles in Beijing, Beijing, 100081, China \\ awushengqingzhu@163.com, ${ }^{\mathrm{b}}$ wangjingbit98@bit.edu.cn, ${ }^{\mathrm{c}} \mathrm{csbit} @ b i t . e d u . c n$, \\ wufeng863@bit.edu.cn \\ ${ }^{*}$ Corresponding author
}

Keywords: Magnetite, Metallic Cu, Fibrous Structure, Anode, Lithium Ion Batteries.

\begin{abstract}
In this paper, a new composite with $\mathrm{Fe}_{3} \mathrm{O}_{4}$ and $\mathrm{Cu}$ nanoparticles encapsulated in carbon nanofibers (CNFs) and its electrochemical properties were reported. The composite is fabricated by a simple electrospinning technique followed by heat treatment. At a current density of $100 \mathrm{~mA} \mathrm{~g}^{-1}$, this electrode exhibits a high reversible capacity of $540.5 \mathrm{mAh} \mathrm{g}^{-1}$ after 100 cycles. Moreover, this composite electrode also shows good rate capability when current density increased from 0.1 to 5.0 $\mathrm{Ag}^{-1}$. This excellent performances can be ascribed to the novel fiber architecture and $\mathrm{Cu}$ introduction. $\mathrm{Cu}$ nanocrystal in the CNFs ensures the composite a good conductive ability.
\end{abstract}

\section{Introduction}

In recent years, rechargeable lithium-ion batteries (LIBs) have been intensively used in clean energy storage, especially portable electronics[1]. However, there is a pressing challenge to develop more advanced LIBs for satisfying the application demands in electric vehicles (EVs) [2]. At present, commercial graphite anode because of its theoretical limit $\left(372 \mathrm{mAh} \mathrm{g}^{-1}\right)$ is difficult to meet the higher capability requirement of LIBs for EV. Many transition metal oxides $\left(\mathrm{MO}_{\mathrm{x}}, \mathrm{M}: \mathrm{Fe}, \mathrm{Sn}\right.$, $\mathrm{Cu}$, etc.) [3-5] have been involved in the development of LIBs anodes materials due to their higher specific capacities. As a promising anode, Ferriferous oxide $\left(\mathrm{Fe}_{3} \mathrm{O}_{4}\right)$ has attracted comprehensive attention on the basis of its high theoretical capacity of $924 \mathrm{mAh} \mathrm{g}^{-1}$, relatively low-cost and good electrochemical activity [6]. However, the large volume expansion (93\%) during charge/discharge and the low conductivity for $\mathrm{Fe}_{3} \mathrm{O}_{4}$ are messy problems for power battery application demands in capacity and good cycling stability [7].

In order to overcome the above complex problems, downsizing various $\mathrm{Fe}_{3} \mathrm{O}_{4}$-based materials is one of promising approaches to the mechanical instabilities of $\mathrm{Fe}_{3} \mathrm{O}_{4}$. Firstly, various carbon material (nanofiber, nanotube, graphene, etc) is usually exploited as a matrix to load $\mathrm{Fe}_{3} \mathrm{O}_{4}$ nanoparticles, taking full advantage of physical stability and electrical conductivity [8,9]. Secondly, the excellent conductive metals $(\mathrm{Ag}, \mathrm{Cu}$,) have been introduced, which can significantly increases the rate performance of material.

Herein, we tried to design a composite with $\mathrm{Fe}_{3} \mathrm{O}_{4}$ and $\mathrm{Cu}$ nanocrystals $\left(5.96 \times 10^{7} \mathrm{~S} \mathrm{~m}^{-1}\right)$ encapsulated in CNFs by a simple electrospinning technique and heat treatment, which can merge the characteristics of $\mathrm{CNF}$ and $\mathrm{Cu}$ to enhance the electrochemical performance of the $\mathrm{Fe}_{3} \mathrm{O}_{4}$-based anode. The detailed synthesis process of the composite is illuminated in Fig. 1. In this synthesis, $\mathrm{Fe}\left(\mathrm{NO}_{3}\right)_{3}$ and $\mathrm{Cu}\left(\mathrm{CH}_{3} \mathrm{COO}\right)_{2}$ will be simultaneously implanted into Polyvinyl Pyrrolidone (PVP) fibers by electrospinning. By the followed heat treatment, $\mathrm{Fe}_{3} \mathrm{O}_{4}$ and $\mathrm{Cu}$ particles may generate in situ in the carbonized nanofibers. The structure and morphologies of the composite are discussed in detail. 


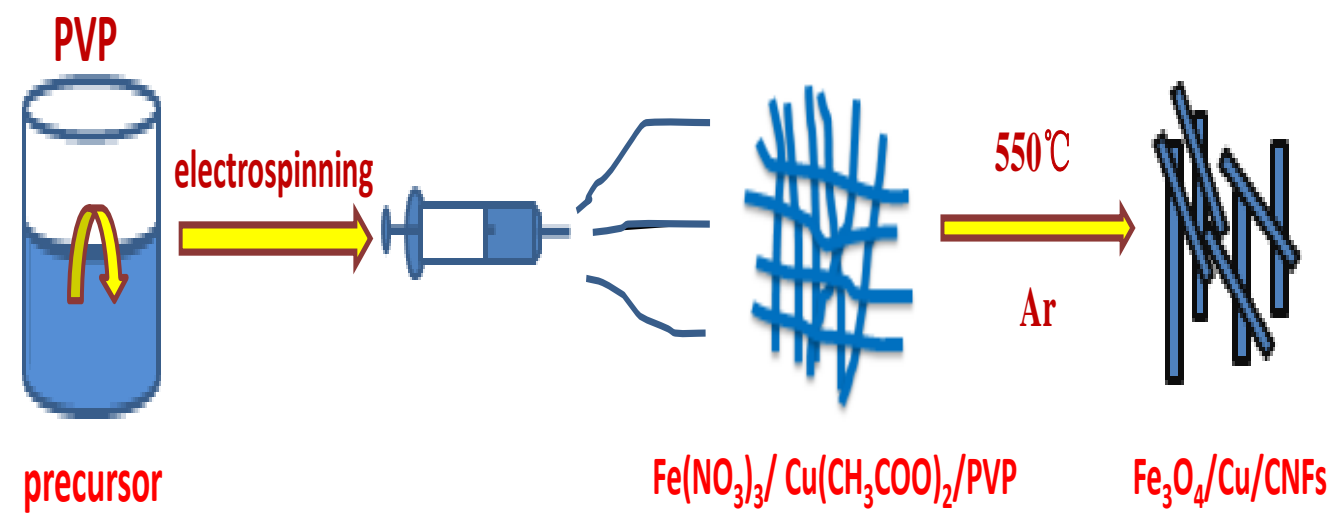

Fig. 1 Schematic illustration of the formation process of the $\mathrm{Fe}_{3} \mathrm{O}_{4} / \mathrm{Cu} / \mathrm{CNFs}$ composite

\section{Experimental}

\section{Material Preparation}

All the reagents were analytical grade without further purification. Polyvinyl Pyrrolidone (PVP, $\mathrm{M}_{\mathrm{w}}=1300$ 000, Aladdin) was used to fabricate the precursor fibers. $\mathrm{Cu}\left(\mathrm{CH}_{3} \mathrm{COO}\right)_{2} \cdot 2 \mathrm{H}_{2} \mathrm{O}$ and $\mathrm{Fe}\left(\mathrm{NO}_{3}\right)_{3} \cdot 9 \mathrm{H}_{2} \mathrm{O}$ were purchased from Beijing Chemical Works.

Electrospinning solution was prepared by dissolving $1 \mathrm{~g}$ PVP in $10 \mathrm{~mL} \mathrm{~N}$, N-dimethylformamide (DMF) with stirring at $40^{\circ} \mathrm{C}$ for $1 \mathrm{~h}$. Then, $0.8 \mathrm{~g}$ of $\mathrm{Fe}\left(\mathrm{NO}_{3}\right)_{3} \cdot 9 \mathrm{H}_{2} \mathrm{O}$ and $0.2 \mathrm{~g}$ of $\mathrm{Cu}\left(\mathrm{CH}_{3} \mathrm{COO}\right)_{2} \cdot 2 \mathrm{H}_{2} \mathrm{O}$ was added to the resulting solution with further stirring at $40^{\circ} \mathrm{C}$ for $12 \mathrm{~h}$. The obtained solution was added in a $10 \mathrm{ml}$ syringe with stainless steel needles. For the electrospinning (SS-2534, Beijing Ucalery Company), a high voltage of $15 \mathrm{kV}$ and flow rate of $0.5 \mathrm{~mL} / \mathrm{h}$ were adopted, and the needle-to-collector distance was $14 \mathrm{~cm}$. After electrospinning process, the electrospun $\mathrm{PVP} / \mathrm{Fe}\left(\mathrm{NO}_{3}\right)_{3} / \mathrm{Cu}\left(\mathrm{CH}_{3} \mathrm{COO}\right)_{2}$ fibers were peeled off from the collector and dried in a vacuum oven at $80^{\circ} \mathrm{C}$ for $12 \mathrm{~h}$. This sample was carbonized at $550^{\circ} \mathrm{C}$ for $2 \mathrm{~h}$ under argon atmosphere with a heating rate $5^{\circ} \mathrm{Cmin}^{-1} . \mathrm{Fe}_{3} \mathrm{O}_{4} / \mathrm{CNFs}$ and $\mathrm{CNFs}$ composites were also fabricated using the similar process.

\section{Characterization}

Scanning electron microscope (FEI QUANTA 6000) and high-resolution transmission electron microscope (HR-TEM, FEI TECNAIG2 F30) were used to investigate the morphologies and microstructure of $\mathrm{Fe}_{3} \mathrm{O}_{4} / \mathrm{Cu} / \mathrm{CNFs}$ and their precursor fibers. The crystal structure was measured by $\mathrm{X}$-ray diffraction using an Ultima IV diffractometer with $\mathrm{Cu}$ Ka radiation at a scan rate of $8^{\circ} \min ^{-1}$ from $10^{\circ}$ to $90^{\circ}$.

\section{Electrochemical Characterization}

The working electrodes consisted of active materials $\left(\mathrm{Fe}_{3} \mathrm{O}_{4} / \mathrm{Cu} / \mathrm{CNFs}, \mathrm{Fe}_{3} \mathrm{O}_{4}\right.$ and $\left.\mathrm{CNFs}\right)$, conductive agent (acetylene black) and binder (poly vinylidene fluoride) ( $8: 1: 1$ in weight ratio), which were dissolved in methyl pyrrolidinone to form a viscous slurry. The above slurry was coated on a copper foil and dried in the vacuum oven at $80^{\circ} \mathrm{C}$ for $12 \mathrm{~h}$ to form electrode film. CR2025 coin half-cells were assembled in an Ar-filled glove box , in which moisture and oxygen levels were less than $1 \mathrm{ppm}$ using lithium foils as the counter electrode and Celgard 2300 film as the separator The electrolyte was $1 \mathrm{~mol} \mathrm{~L}^{-1} \mathrm{LiPF}_{6} / \mathrm{DMC}+\mathrm{DEC}+\mathrm{EC}$ solution $(1: 1: 1$ in volume). Galvanostatic charge-discharge tests of the cells were measured by a Land 2001A CT battery tester ( $\left.\mathrm{vs} \mathrm{Li}^{+} / \mathrm{Li}\right)$. Cyclic voltammetry $(\mathrm{CV})$ of the electrode was measured at a scan rate of $0.1 \mathrm{mV} \mathrm{s}^{-1}$ within the range of 0.01-3.00 V. Electrochemical impedance spectroscopy (EIS) was performed on an electrochemical workstation (CHI 660C) under the frequency range from $100 \mathrm{kHz}$ to $10 \mathrm{mHz}$. 


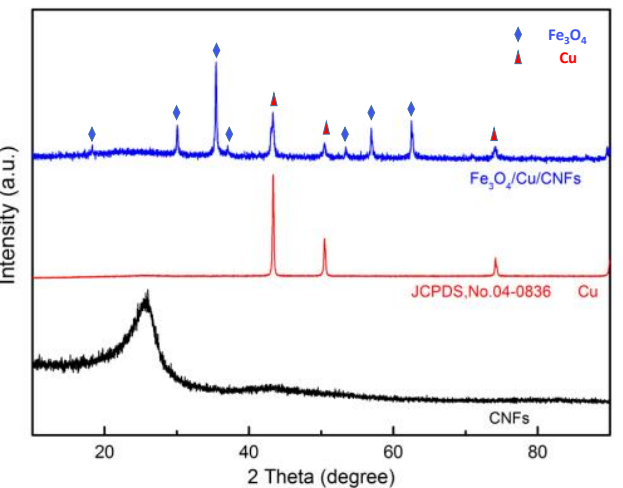

Fig. 2 (a) XRD patterns of $\mathrm{CNFs}, \mathrm{Cu}$ and $\mathrm{Fe}_{3} \mathrm{O}_{4} / \mathrm{Cu} / \mathrm{CNF}$ s composite.

In order to compare crystal structure and phase composition, the patterns of $\mathrm{Fe}_{3} \mathrm{O}_{4} / \mathrm{Cu} / \mathrm{CNFs}$, pure $\mathrm{Fe}_{3} \mathrm{O}_{4}$ and $\mathrm{Cu}$ determined by XRD are shown in Fig.2. In the pattern of CNFs, there are two broad peaks at $2 \theta=26^{\circ}$ and $43^{\circ}$, implying the (002) and (100) planes of carbon with a non-graphitized structure[10]. The peaks appearing at $2 \theta=18.3,30.1,35.4,37.1,43.0,47.1,53.4$, $56.9,62.5,70.9,73.9$ and $86.7^{\circ}$ correspond to the cubic phase of $\mathrm{Fe}_{3} \mathrm{O}_{4}$ with the planes of (111), (220), (311), (222), (400), (422), (511), (440), (620), (533) and (642)[11]. Respectively, all of the reflection peaks for both raw $\mathrm{Fe}_{3} \mathrm{O}_{4}$ and $\mathrm{Fe}_{3} \mathrm{O}_{4} / \mathrm{Cu} / \mathrm{CNFs}$ can be indexed to face-centered-cubic magnetite $\mathrm{Fe}_{3} \mathrm{O}_{4}$ (JCPDS, no. 99-0073). The obviously high background of composite in the XRD pattern indicates the presence of amorphous carbon[9]. Besides, the diffraction peaks of metallic $\mathrm{Cu}$ at 43.3, 50.4 and $74.1^{\circ}$ are indexed to the (111), (200) and (220) planes (JCPDS, no. 04-0836)[12]. These study results demonstrate the composite fibers comprised of $\mathrm{Fe}_{3} \mathrm{O}_{4}, \mathrm{Cu}$ and carbon phases have been successful prepared by electrospinning and subsequent treatment.
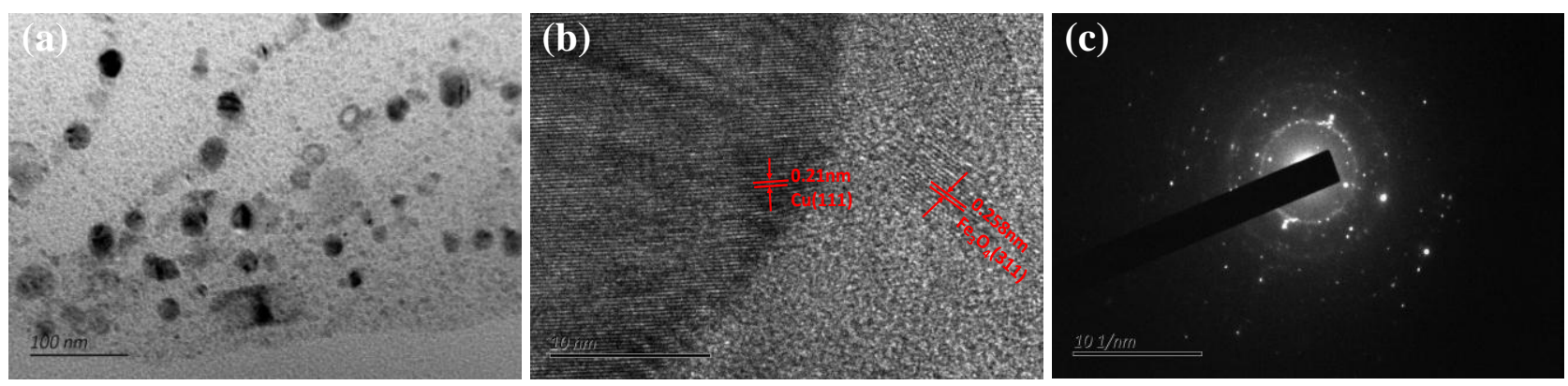

Fig. 3 (a, b) HRTEM images of $\mathrm{Fe}_{3} \mathrm{O}_{4} / \mathrm{Cu} / \mathrm{CNFs}$ composite, (c) FFT pattern of $\mathrm{Fe}_{3} \mathrm{O}_{4} / \mathrm{Cu} / \mathrm{CNFs}$ composite.

Fig. 3a and $3 \mathrm{~b}$ show TEM images of $\mathrm{Fe}_{3} \mathrm{O}_{4} / \mathrm{C}$ composite architecture. Clearly, the uniform $\mathrm{Fe}_{3} \mathrm{O}_{4}$ and $\mathrm{Cu}$ crystals are homogeneously embedded in the CNFs without apparent agglomeration. The particle size has an average diameter of $\sim 15-30 \mathrm{~nm}$, which is well consistent with the calculated result from Scherrer's formula. The HRTEM image in Figure $3 \mathrm{~b}$ demonstrates a typical $\mathrm{Fe}_{3} \mathrm{O}_{4}$ particle with good crystalline texture. The d-spacings of $0.258 \mathrm{~nm}$ are in good consistent with the (311) planes[13], respectively. Besides, the well-resolved lattice fringe distance of $0.21 \mathrm{~nm}$ can be indexed to the (111) plane of single-crystalline $\mathrm{Cu}$ [14]. The ambient phase exhibiting an amorphous structure is good agreement with the carbon host. 

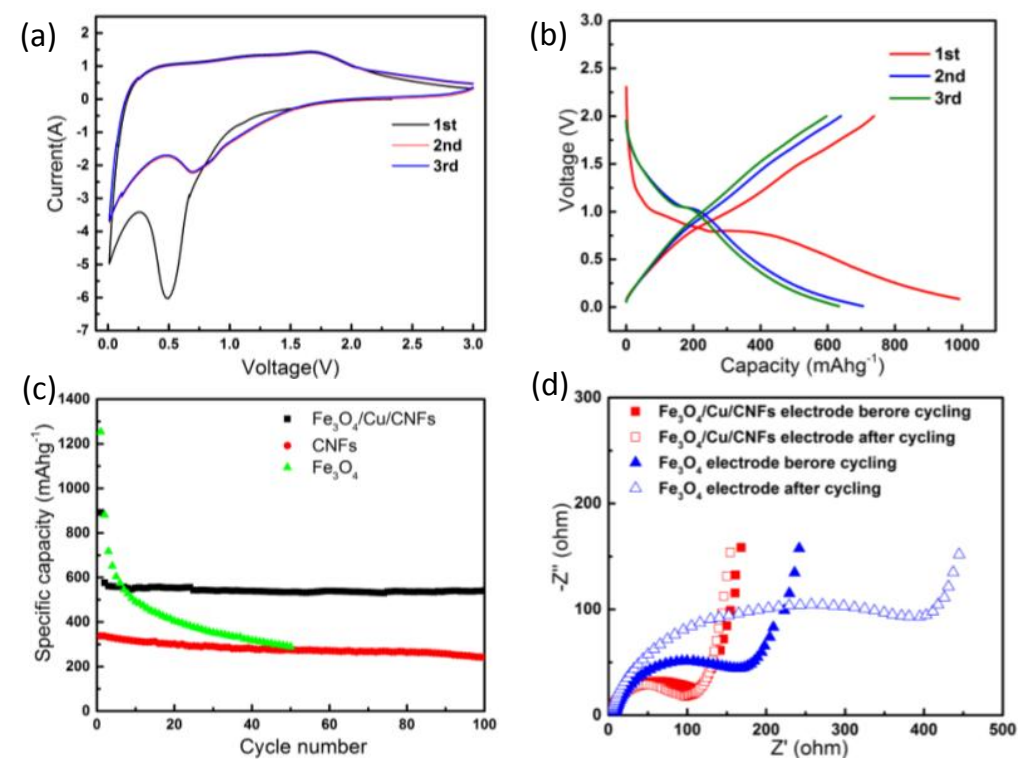

Fig. 4 Electrochemical performance of $\mathrm{Fe}_{3} \mathrm{O}_{4} / \mathrm{Cu} / \mathrm{CNFs}$ anodes

(a) $\mathrm{CVs}$ of $\mathrm{Fe}_{3} \mathrm{O}_{4} / \mathrm{Cu} / \mathrm{CNFs}$ anode $\left(0.1 \mathrm{mV} \mathrm{s}^{-1}\right)$

(b) Discharge/charge profiles of $\mathrm{Fe}_{3} \mathrm{O}_{4} / \mathrm{Cu} / \mathrm{CNF}$ anodes cycled between 0.01 and $2.0 \mathrm{~V}$ at a current density of $100 \mathrm{~mA} \mathrm{~g}^{-1}$

(c) Cycling performances of $\mathrm{Fe}_{3} \mathrm{O}_{4} / \mathrm{Cu} / \mathrm{CNFs}$, pure $\mathrm{Fe}_{3} \mathrm{O}_{4}$, and $\mathrm{CNFs}$ anodes at $100 \mathrm{mAg}^{-1}$

(d) Impedance spectra of $\mathrm{Fe}_{3} \mathrm{O}_{4} @ \mathrm{PCF}$ anode before cycling and after cycling respectively

The electrochemical measurements of $\mathrm{Fe}_{3} \mathrm{O}_{4} / \mathrm{Cu} / \mathrm{CNFs}$ composite anode are presented in Fig. 4. Fig. 4a shows the cyclic voltammograms curves of $\mathrm{Fe}_{3} \mathrm{O}_{4} / \mathrm{Cu} / \mathrm{CNF}$ composite electrode at a scan rate of $0.1 \mathrm{mVs}^{-1}$. An obvious cathodic peak is observed during the first cycle at the potential of $0.5 \mathrm{~V}$ in the first cathodic curve, which can be attributed to the electrochemical lithiation process of $\mathrm{Fe}_{3} \mathrm{O}_{4}$ and the formation of solid electrolyte interphase (SEI).

$$
\begin{aligned}
& \mathrm{Fe}_{3} \mathrm{O}_{4}+2 \mathrm{Li}^{+}+2 e^{-} \rightarrow \mathrm{Li}_{2}\left(\mathrm{Fe}_{3} \mathrm{O}_{4}\right) \\
& \mathrm{Li}_{2}\left(\mathrm{Fe}_{3} \mathrm{O}_{4}\right)+6 \mathrm{Li}^{+}+6 \mathrm{e}^{-} \rightarrow 3 \mathrm{Fe}^{0}+4 \mathrm{Li}_{2} \mathrm{O} \\
& 3 \mathrm{Fe}^{0}+4 \mathrm{Li}_{2} \mathrm{O} \rightarrow \mathrm{Fe}_{3} \mathrm{O}_{4}+2 \mathrm{Li}^{+}+2 \mathrm{e}^{-}
\end{aligned}
$$

From the 2 nd $\mathrm{CV}$ cycle, a cathodic peak observed at 0.69 corresponds to the reduction reaction (eq 2 and 3), which indicates that a stable SEI film has been formed on the surface of carbon shell during the first cycle. In the first anodic half-cycles, the anodic peak at $1.75 \mathrm{~V}$ corresponds to the oxidation process of $\mathrm{Fe}^{0}$ to $\mathrm{Fe}_{3} \mathrm{O}_{4}$ (eq 3 ). The $\mathrm{CV}$ curves from the $2^{\text {nd }}$ cycle with no apparent shift indicates that the $\mathrm{Fe}_{3} \mathrm{O}_{4} / \mathrm{Cu} / \mathrm{CNF}$ electrode shows an excellent reversibility during charge and discharge processes[15]. The discharge/charge profiles of $\mathrm{Fe}_{3} \mathrm{O}_{4} / \mathrm{Cu} / \mathrm{CNFs}$ between 0.01 and $2.0 \mathrm{~V}$ for different cycles at a current density of $100 \mathrm{~mA} \mathrm{~g}^{-1}$ are shown in Fig. $4 \mathrm{~b}$. In the first lithiation and delithiation process, the bare $\mathrm{Fe}_{3} \mathrm{O}_{4}$ electrode shows a specific capacity of 1216.3 and $879.5 \mathrm{mAh}$ $\mathrm{g}^{-1}$ with a Coulombic efficiency of $72.3 \%$. It is noted that there are two voltage plateaus at $1.0 \mathrm{~V}$ and $0.7 \mathrm{~V}$ in the first discharge cycle, but only one plateau at $0.8 \mathrm{~V}$ in the subsequent cycles, which are good agreement with the cathodic and anodic peaks in the 1 st CV curve (Fig. 4a).

The cycling performance of the $\mathrm{Fe}_{3} \mathrm{O}_{4} / \mathrm{Cu} / \mathrm{CNFs}$, pure $\mathrm{Fe}_{3} \mathrm{O}_{4}$, composite electrode at a current density of $100 \mathrm{mAg}^{-1}$ are shown in Fig. 4c. The initial discharge capacity of pure $\mathrm{Fe}_{3} \mathrm{O}_{4}$ electrode decreasing from 1318 to $292 \mathrm{mAh} \mathrm{g}^{-1}$ after 50 cycles shows a rapid fading trend. During the cycling process, because of the large volume change of $\mathrm{Fe}_{3} \mathrm{O}_{4}$ and direct contact with the electrolyte, the SEI would be destroyed and formed repeatedly leading to a poor cycling performance [16]. Compared with the pure $\mathrm{Fe}_{3} \mathrm{O}_{4} \mathrm{NPs}$, The $\mathrm{Fe}_{3} \mathrm{O}_{4} / \mathrm{Cu} / \mathrm{CNF}$ s composite electrode keeps a high discharge capacity of $540.5 \mathrm{mAh} \mathrm{g}^{-1}$ after 100 cycles, which is more than the value of CNFs $(371.4$ 
$\mathrm{mAh} \mathrm{g}^{-1}$ ) under the same experimental conditions. The superior capacity stability of $\mathrm{Fe}_{3} \mathrm{O}_{4} / \mathrm{Cu} / \mathrm{CNFs}$ can be mainly attributed to the designed hierarchical structure, where active particles are implanted into carbon framework. This novel structure is helpful to block solvents of electrolyte and prevent the active material from agglomeration and pulverization upon continuous cycling.

In order to investigate the changes of electrical conductivity, EIS measurements are measured for $\mathrm{Fe}_{3} \mathrm{O}_{4} / \mathrm{Cu} / \mathrm{CNFs}$ and $\mathrm{Fe}_{3} \mathrm{O}_{4}$ electrode before and after cycling (Fig. 4d). All the three Nyquist plots contain one semicircle at high frequencies attributed to a charge-transfer phenomenon, and an inclined line at low frequencies ascribed to the mass-transfer process[17]. It is noted that the charge transfer resistance $\left(\mathrm{R}_{\mathrm{ct}}\right)$ of the $\mathrm{Fe}_{3} \mathrm{O}_{4} / \mathrm{Cu} / \mathrm{CNFs}$ electrode is $112 \Omega$ for the fresh cell, which is apparently smaller than that of the pure $\mathrm{Fe}_{3} \mathrm{O}_{4}$ electrode $(163 \Omega)$. This comparison means the composite electrode has a stronger electrochemical reactivity and higher charge-transfer rate. After charge-discharge for 100 cycles, its charge transfer resistance decreases to $88.3 \Omega$, which may be due to more sufficient contact between active materials and the electrolyte in this case. On the contrary, the resistance Rct of bare $\mathrm{Fe}_{3} \mathrm{O}_{4}$ electrodes increases dramatically after 100 cycles from 163.8 to $395 \Omega$. This phenomenon may be ascribed to electrode degradation after long cycles of lithiation/delithiation.
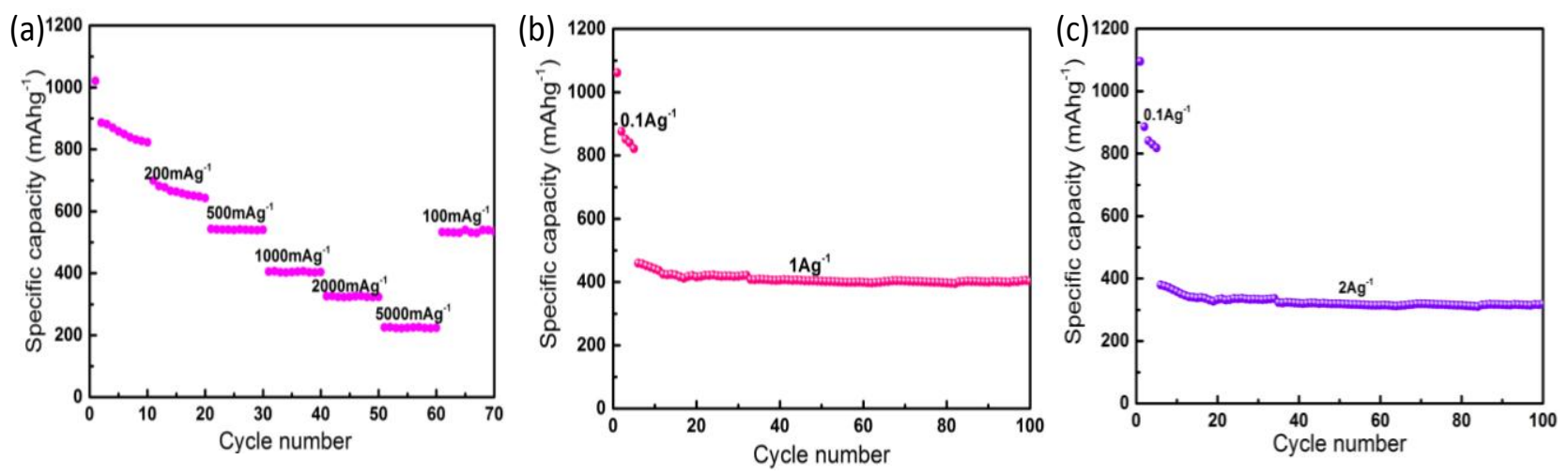

Fig. 5 (a) Rate performance of the $\mathrm{Fe}_{3} \mathrm{O}_{4} / \mathrm{Cu} / \mathrm{CNFs}$ composite at various current densities, (b) (c) cycling performance of the $\mathrm{Fe}_{3} \mathrm{O}_{4} / \mathrm{Cu} / \mathrm{CNFs}$ composite at current densities of 1.0 and $2.0 \mathrm{~A}$ g- 1

The excellent rate capability of the $\mathrm{Fe}_{3} \mathrm{O}_{4} / \mathrm{Cu} / \mathrm{CNFs}$ composites was showed in Fig. 5a. When the current densities increases from 0.2 to $0.5,1.0,2.0$ and $5.0 \mathrm{~A} \mathrm{~g}^{-1}, \mathrm{Fe}_{3} \mathrm{O}_{4} / \mathrm{Cu} / \mathrm{CNFs}$ composites deliver a reversible capacity of $620,548.8,405,325.8,195 \mathrm{mAh} \mathrm{g}^{-1}$, respectively. After the high-rate test, the reversible capacity of $\mathrm{Fe}_{3} \mathrm{O}_{4} / \mathrm{C}$ electrode will recover to $530.8 \mathrm{mAh} \mathrm{g}^{-1}$ at 100 $\mathrm{mAh} \mathrm{g}^{-1}$. Besides, when the current densities are 1000 and $2000 \mathrm{~mA} \mathrm{~g}^{-1}$, it exhibits 405 and 331.5 $\mathrm{mAh} \mathrm{g}^{-1}$ reversible capacities after 100 cycles, respectively (Fig. 5b, 5c). The superior rate capacity may be attributed to the implanted $\mathrm{Cu}$ and one-dimensional structure CNFs support. Metallic $\mathrm{Cu}$ possessing a high conductivity is helpful to improving the electrical the Composite material conductivity.

\section{Conclusions}

In summary, we synthesized successfully a novel $\mathrm{Fe}_{3} \mathrm{O}_{4} / \mathrm{Cu} / \mathrm{CNF}$ s composite by a simple electrospinning method and subsequent carbonization. $\mathrm{Fe}_{3} \mathrm{O}_{4}$ and $\mathrm{Cu}$ particles were embedded controllably in carbon framework without apparent agglomeration. The composite electrode shows superior electrochemical properties with high specific capacities, long cycling life and excellent rate performance. This superior performance, especially the rate capability, is mainly attributed to dispersed $\mathrm{Fe}_{3} \mathrm{O}_{4}$ and $\mathrm{Cu}$ nanocrystals and one-dimensional structural $\mathrm{CNFs}$ which make a significant contribution to reduce the Li ions transport pathway. Besides, the introduced metallic $\mathrm{Cu}$ plays a huge role in the modification of the rate performance. 


\section{Acknowledgments}

This work was financially supported by the National Key R\&D Program (Grant No. 2016YFB0100400). We also thank the support from the Special fund of Beijing Co-construction Project.

\section{References}

[1] M. Armand, J.-M. Tarascon, Building better batteries, Nature. 451 (2008) 652-657.

[2] B. Dunn, H. Kamath, J.-M. Tarascon, Electrical energy storage for the grid: a battery of choices, Science. 334 (2011) 928-935.

[3] M. Reddy, G. Subba Rao, B. Chowdari, Metal oxides and oxysalts as anode materials for Li ion batteries, Chem. Rev. 113 (2013) 5364-5457.

[4] X. Guan, J. Nai, Y. Zhang, CoO hollow cube/reduced graphene oxide composites with enhanced lithium storage Capability, Chem. Mater. 26 (2014) 5958-5964.

[5] X. Sun, W. Si, X. Liu, Multifunctional Ni/NiO hybrid nanomembranes as anode materials for high-rate Li-ion batteries, Nano Energy. 9 (2014) 168-175.

[6] H.B. Wu, J.S. Chen, H.H. Hng, Nanostructured metal oxide-based materials as advanced anodes for lithium-ion batteries, Nanoscale. 4 (2012) 2526-2542.

[7] S.H. Lee, S.H. Yu, J.E. Lee, Self-Assembled $\mathrm{Fe}_{3} \mathrm{O}_{4}$ nanoparticle clusters as high-performance anodes for lithium ion batteries via geometric confinement, Nano letters. 13 (2013) 4249-4256.

[8] P. Wang, M. Gao, H. Pan, A facile synthesis of $\mathrm{Fe}_{3} \mathrm{O}_{4} / \mathrm{C}$ composite with high cycle stability as anode material for lithium-ion batteries, J. Power Sources. 239 (2013) 466-474.

[9] Z. Zeng, H. Zhao, J. Wang, Nanostructured $\mathrm{Fe}_{3} \mathrm{O}_{4} @ \mathrm{C}$ as anode material for lithium-ion batteries, J. Power Sources. 248 (2014) 15-21.

[10]L. Qie, W.M. Chen, Nitrogen-doped porous carbon nanofiber webs as anodes for lithium ion batteries with a superhigh capacity and rate capability, Adv. Mater. 24 (2012) 2047-2050.

[11]F. Wu, R. Huang, D. Mu, New synthesis of a foamlike $\mathrm{Fe}_{3} \mathrm{O}_{4} / \mathrm{C}$ composite via a self-expanding process and its electrochemical performance as anode material for lithium-ion batteries, ACS Appl. Mater. Interfaces. 6 (2014) 19254-19264.

[12]F.F. Cao, J.W. Deng, S. Xin, Cu-Si nanocable arrays as high-rate anode materials for Lithium-ion batteries, Adv. Mater. 23 (2011) 4415-4420.

[13]S. Gu, Y. Liu, G. Zhang, $\mathrm{Fe}_{3} \mathrm{O}_{4} /$ carbon composites obtained by electrospinning as an anode material with high rate capability for lithium ion batteries, RSC Adv. 4 (2014) 41179-41184.

[14]C.S. Choi, Y.-U. Park, H. Kim, Three-dimensional sponge-like architectured cupric oxides as high-power and long-life anode material for lithium rechargeable batteries, Electrochimica Acta. 70 (2012) 98-104.

[15]C. He, S. Wu, N. Zhao, Carbon-encapsulated $\mathrm{Fe}_{3} \mathrm{O}_{4}$ nanoparticles as a high-rate lithium ion battery anode material, ACS nano. 7 (2013) 4459-4469.

[16]N. Zhao, S. Wu, One-pot synthesis of uniform $\mathrm{Fe}_{3} \mathrm{O}_{4}$ nanocrystals encapsulated in interconnected carbon nanospheres for superior lithium storage capability, Carbon. 57 (2013) 130-138.

[17]T.H. Hwang, Y.M. Lee, B.-S. Kong, Electrospun core-shell fibers for robust silicon nanoparticle-based lithium ion battery anodes, Nano letters. 12 (2012) 802-807. 